\title{
POWDER-METALLURGY PREPARATION OF NiTi SHAPE-MEMORY ALLOY USING MECHANICAL ALLOYING AND SPARK-PLASMA SINTERING
}

\author{
UPORABA METALURGIJE PRAHOV ZA PRIPRAVO NiTi ZLITINE \\ S SPOMINOM S POMOČJO MEHANSKEGA LEGIRANJA IN \\ SINTRANJA Z ISKRILNO PLAZMO
}

\author{
Pavel Novák ${ }^{1}$, Hynek Moravec ${ }^{1}$, Vladimír Vojtěch ${ }^{1}$, Anna Knaislová1, \\ Andrea Školákovái, Tomáš František Kubatík ${ }^{2}$, Jaromír Kopeček ${ }^{3}$ \\ ${ }^{1}$ Institute of Chemical Technology, Department of Metals and Corrosion Engineering, Technická 5, 16628 Prague 6, Czech Republic \\ ${ }^{2}$ Institute of Plasma Physics AS CR, v.v.i., Za Slovankou 3, 18200 Prague 8, Czech Republic \\ ${ }^{3}$ Institute of Physics of the ASCR, v. v. i., Na Slovance 2, 18221 Prague 8, Czech Republic \\ panovak@vscht.cz
}

Prejem rokopisa - received: 2016-01-13; sprejem za objavo - accepted for publication: 2016-02-02

doi: $10.17222 / \mathrm{mit} .2016 .011$

\begin{abstract}
In this work a combination of mechanical alloying and spark-plasma sintering was tested as a promising route for the preparation of a nanocrystalline NiTi shape-memory alloy. The mechanism of mechanical alloying was investigated. Results revealed that the $\mathrm{Ti}_{2} \mathrm{Ni}$ phase forms preferentially, being followed by the NiTi phase (austenite B2 structure) and a small amount of $\mathrm{Ni}_{3} \mathrm{Ti}$. During spark-plasma sintering, only minor changes occurred in the phase composition, i.e., precipitation of the $\mathrm{Ni}_{4} \mathrm{Ti}_{3}$ phase and the partial transformation of NiTi to monoclinic martensite. The selected technology leads to a very high compression strength (approx. $2300 \mathrm{MPa}$ ), but also high brittleness.
\end{abstract}

Keywords: mechanical alloying, spark plasma sintering, NiTi, shape memory alloy

$\mathrm{V}$ delu je bila preizkušena kombinacija mehanskega legiranja in sintranja z iskrilno plazmo, ki predstavlja obetajoč način za pripravo nanokristalne NiTi spominske zlitine. Preiskovan je bil mehanizem mehanskega legiranja. Rezultati so odkrili, da se najprej tvori faza $\mathrm{Ti}_{2} \mathrm{Ni}$, ki ji sledi faza NiTi (avstenitna B2 struktura) in manjši delež $\mathrm{Ni}_{3} \mathrm{Ti}_{\text {. }}$ Med sintranjem z iskrilno plazmo se pojavijo le manjše razlike $\mathrm{v}$ sestavi faz, to je izločanje faze $\mathrm{Ni}_{4} \mathrm{Ti}_{3}$ in delna pretvorba $\mathrm{NiTi} \mathrm{v}$ monoklinski martenzit. Izbrana tehnologija povzroči veliko tlačno trdnost (okoli $2300 \mathrm{MPa}$ ) in tudi veliko krhkost materiala.

Ključne besede: mehansko legiranje, sintranje z iskrilno plazmo, NiTi, zlitina z oblikovnim spominom

\section{INTRODUCTION}

The approximately equimolar Ni-Ti alloy, called nitinol, is the most widely used shape-memory alloy. The shape-memory effect in this alloy is connected with the transformation between high-temperature cubic austenite (B2 structure) and low-temperature monoclinic martensite (B19' structure). ${ }^{1}$ Due to its exceptional properties, the NiTi alloy is applied in both medical (dental implants, stents, scaffolds) ${ }^{2}$ and technical applications (actuators, robotics, etc.). ${ }^{3}$

As an alternative to conventional production methods for the NiTi alloy (vacuum induction melting and vacuum arc remelting), powder-metallurgy processes starting from pre-alloyed NiTi powder have been developed. ${ }^{4}$

An alternative powder-metallurgy process for the production of ceramics or intermetallics is reaction synthesis. In this process, the compressed mixture of elemental powders is transformed to intermetallic, thermally activated exothermic reactions. During the reactions, the heat is generated, which sustains and propagates the reaction through the body of the reactants. Therefore, the process is called self-propagating high-temperature synthesis (SHS). ${ }^{5}$ Mechanical alloying is one of the techniques used for the production of nanostructured powders. ${ }^{6}$ Mechanical alloying is in fact high-energy ball milling. In this process, the high kinetic energy of balls causes the following phenomena: crushing of particles leading to the reduction of the particle size, local welding of particles by plastic deformation, friction forces and diffusion, structure refinement due to enormous plastic deformation and the formation of solid solutions and chemical compounds (intermetallics). ${ }^{6}$

Spark-plasma sintering (SPS) is the modern compaction method, which uses uniaxial pressing accompanied by the passage of the electric current through the sample. It causes rapid heating of the sample and discharges between powder particles that can cause local welding of the particles. Due to the high sintering rate during SPS this method is highly suitable for the compaction of nanocrystalline materials and phases with a lower thermal stability. ${ }^{6}$

In our previous paper ${ }^{6}$, we developed a novel mechanical alloying process that allows for the formation of intermetallics in a much shorter time than in previously published papers. ${ }^{7}$ In this work, this improved mecha- 
nical-alloying process on NiTi shape-memory phase synthesis is studied. The combination of this process with spark-plasma sintering for the production of a NiTi shape memory alloy was tested.

\section{EXPERIMENTAL PART}

In this work, the material based on the NiTi shape memory phase was prepared from elemental powders by mechanical alloying and subsequent spark-plasma sintering (SPS) compaction. The mechanical alloying was carried out in a planetary ball mill (Retsch PM 100 CM) under the following conditions, optimized in our previous paper dealing with the synthesis of intermetallics: ${ }^{6}$

- milling duration: 15-360 min,

- change of rotation direction each $15 \mathrm{~min}$,

- rotation speed: $400 \mathrm{~min}^{-1}$,

- atmosphere: argon

- powder batch: $5 \mathrm{~g}$

- ball-to-powder weight ratio: 70:1.

The powder mixtures for milling contained $54 \% \mathrm{Ni}$ and $\% \mathrm{Ti}$ (by weight). This composition corresponds to the equimolar NiTi phase. ${ }^{8}$ Milled powders were examined by X-ray diffraction analysis (PANalytical X'Pert Pro diffractometer, $\mathrm{Cu} K_{\alpha}$ radiation with the wavelength of $0.154060 \mathrm{~nm}$ ) in order to identify the phase composition. The XRD patterns were evaluated using PANalytical HighScore software with the PDF-2 database. XRD patterns were also quantitatively processed using the Rietweld method. Metallographic samples were prepared from selected powders. The microstructure of powder samples was studied after etching by modified Kroll's reagent $\left(10 \mathrm{~mL} \mathrm{HNO}_{3}, 5 \mathrm{~mL} \mathrm{HF}\right.$, $85 \mathrm{~mL} \mathrm{H}_{2} \mathrm{O}$ ). Individual phases in the powders were identified on metallographic samples by chemical microanalysis using TESCAN VEGA 3 LMU scanning electron microscope equipped with OXFORD Instruments X-max EDS SDD $20 \mathrm{~mm}^{2}$ detector (SEM-EDS).

Powder prepared under selected conditions (milling duration of $2 \mathrm{~h}$ ) was compacted by SPS at the Institute of Plasma Physics AS CR. The weight of the batch for sintering was $5 \mathrm{~g}$. Compaction was carried out using a Thermal Technology SPS 10-4 device using a pressure of $70 \mathrm{MPa}$ for $5 \mathrm{~min}$ at various process temperatures with a heating rate of $300 \mathrm{~K} / \mathrm{min}$. The phase composition of the prepared compact samples was determined by XRD. The porosity of compact samples was studied on polished metallographic samples by image analysis using Lucia 4.8 image analyser. The mechanical properties of the SPS-consolidated material were tested in compression using LabTest 5.250SP1-VM universal loading machine (produced by LaborTech).

\section{RESULTS}

The dependence of phase composition of the powders obtained by mechanical alloying on process duration is presented in Figure 1. During this experiment, a constant rotational velocity of $400 \mathrm{rpm}$ and a ball-to-powder ratio of 70:1 were applied. After $15 \mathrm{~min}$ of mechanical alloying, a small amount of $\mathrm{Ti}_{2} \mathrm{Ni}$ phase was formed. In addition to this phase, the obtained powder contained only unreacted initial powders of nickel and titanium. After prolongation of the mechanical alloying process to 30-60 min, the $\mathrm{Ti}_{2} \mathrm{Ni}$ phase still dominated the phase composition and the NiTi phase arose in the XRD patterns. Residual nickel is still present in the powder mixture. Mechanical alloying for 120 min produced a powder composed of $\mathrm{NiTi}$ (austenite structure) and $\mathrm{Ti}_{2} \mathrm{Ni}$ phases (Figure 1). When prolonging the mechanical alloying to $360 \mathrm{~min}$, the $\mathrm{Ti}_{2} \mathrm{Ni}$ still remains in the powder mixture and the new $\mathrm{Fe}_{2} \mathrm{Ti}$ phase arises as a result of the contamination by milling in an iron-based vessel (Figure 1). Therefore, long-term milling cannot be recommended in this system and experimental setup.

The development of the microstructure of the powders during the milling process is shown in Figure 2. A short milling duration $(15 \mathrm{~min})$ results in the lamellar structure containing deformed nickel and titanium particles, which are mechanically bonded (Figure2a). On the interface between these particles, the layers and/or fragmented particles of $\mathrm{Ti}_{2} \mathrm{Ni}$ and traces of NiTi start to form. Prolonging the duration of milling to 30-45 leads to the disappearing of titanium particles (Figure $2 \mathbf{b}$ ). The milling duration of $120 \mathrm{~min}$ creates the structure composed of NiTi matrix with dispersed $\mathrm{Ti}_{2} \mathrm{Ni}$ particles (Figure2c).

During spark-plasma sintering consolidation of the material, new phases precipitated from the mechanically

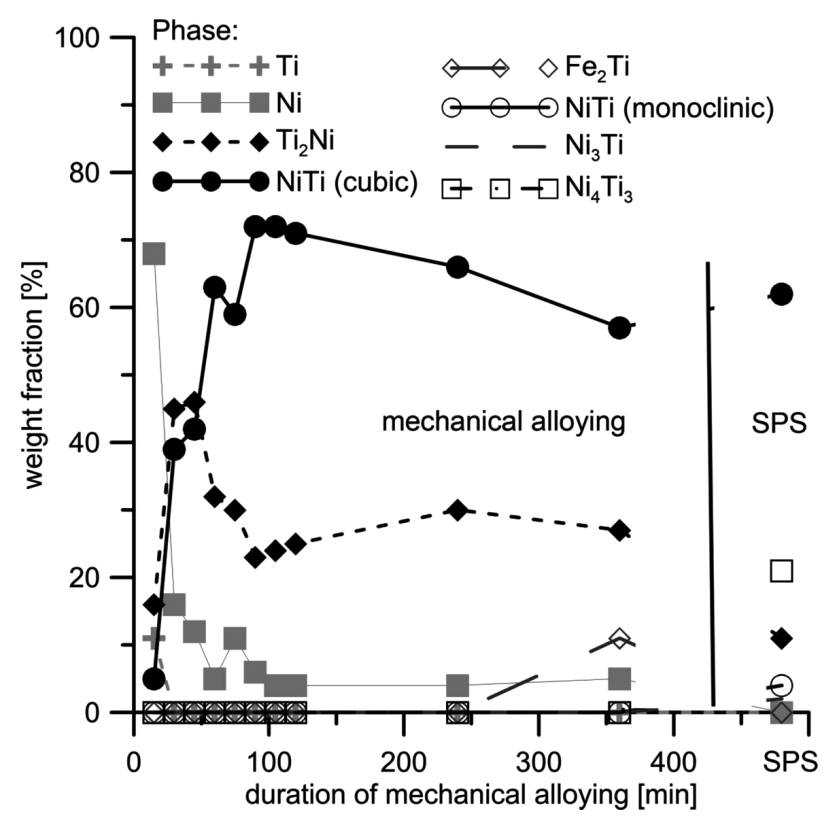

Figure 1: Amounts of phases in milled powders and SPS-consolidated sample (determined by XRD and Rietveld refinement

Slika 1: Količine faz v mletem prahu in vzorcu, konsolidiranem z SPS (določeno z XRD in Rietveld metodo) 

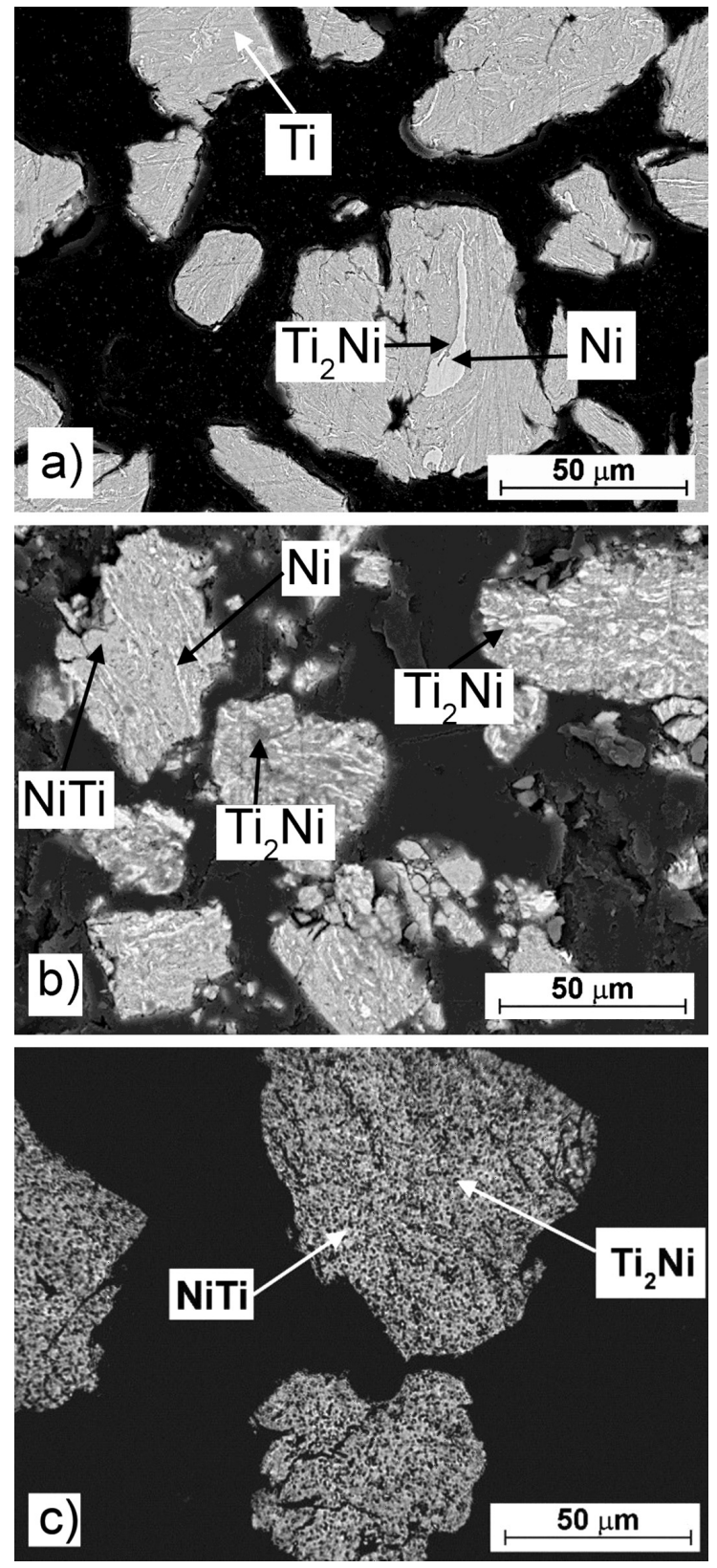

Figure 2: Microstructure of NiTi50 (in amount fractions, a/\%) alloy powder prepared by mechanical alloying for: a) $15 \mathrm{~min}$, b) $45 \mathrm{~min}, \mathrm{c})$ $120 \mathrm{~min}$

Slika 2: Mikrostruktura prahu zlitine NiTi50 (v volumskih deležih, a/\%), pripravljene z mehanskim legiranjem, a) $15 \mathrm{~min}$, b) $45 \mathrm{~min}, \mathrm{c})$ $120 \mathrm{~min}$

alloyed material, i.e., the $\mathrm{Ni}_{4} \mathrm{Ti}_{3}$ and $\mathrm{Ni}_{3} \mathrm{Ti}$ intermetallic phases (Figure 1). Most probably, the $\mathrm{Ni}_{4} \mathrm{Ti}_{3}$ is a result of thermal exposure and compressive stress and $\mathrm{Ni}_{3} \mathrm{Ti}$ originates from the reaction of residual nickel with NiTi phase. In addition, the NiTi phase was found in two crystal modifications: the monoclinic and B2 cubic phase. The product of spark-plasma sintering contains only a low amount of pores (below 1 vol. \%, Figure 3).

The compressive strength of the mechanically alloyed and consolidated NiTi material reaches $2200 \pm$ $90 \mathrm{MPa}$. However, the material exhibits almost brittle

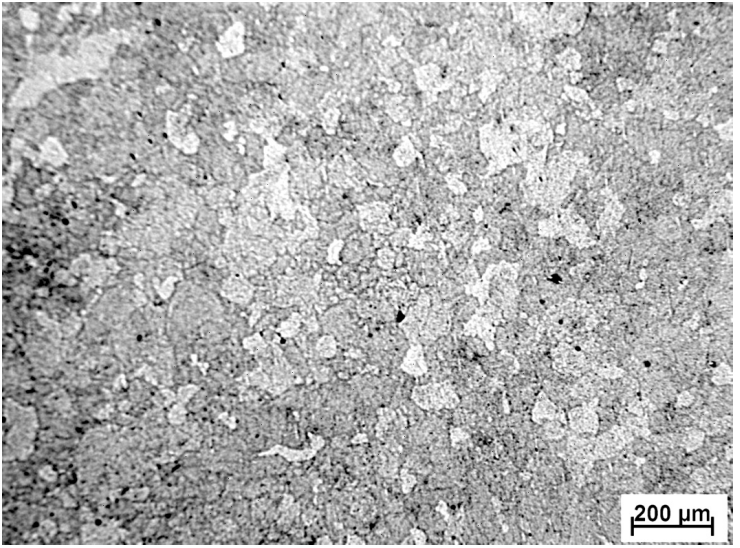

Figure 3: Microstructure of the NiTi alloy prepared by mechanical alloying for $120 \mathrm{~min}$ and spark-plasma sintering at $900{ }^{\circ} \mathrm{C}$ with a heating rate of $300{ }^{\circ} \mathrm{C} \mathrm{min}^{-1}$

Slika 3: Mikrostruktura zlitine $\mathrm{NiTi}$, pripravljene $\mathrm{z}$ mehanskim legiranjem $120 \mathrm{~min}$ in sintranjem $\mathrm{z}$ iskrilno plazmo pri $900{ }^{\circ} \mathrm{C}$, s hitrostjo segrevanja $300{ }^{\circ} \mathrm{C} \mathrm{min}-1$

behaviour (Figure 4), without the signs of the deformation-induced transformation of cubic austenite phase to monoclinic martensite. The reason probably lies in the strong deformation strengthening of the powder during milling. The material did not recover significantly during SPS consolidation due to the short time applied for sintering. Due to this fact, the material does not allow for plastic deformation during loading.

\section{CONCLUSIONS}

In this paper, the Ni-Ti phase evolution during ultrahigh-energy short-term mechanical alloying was investi-

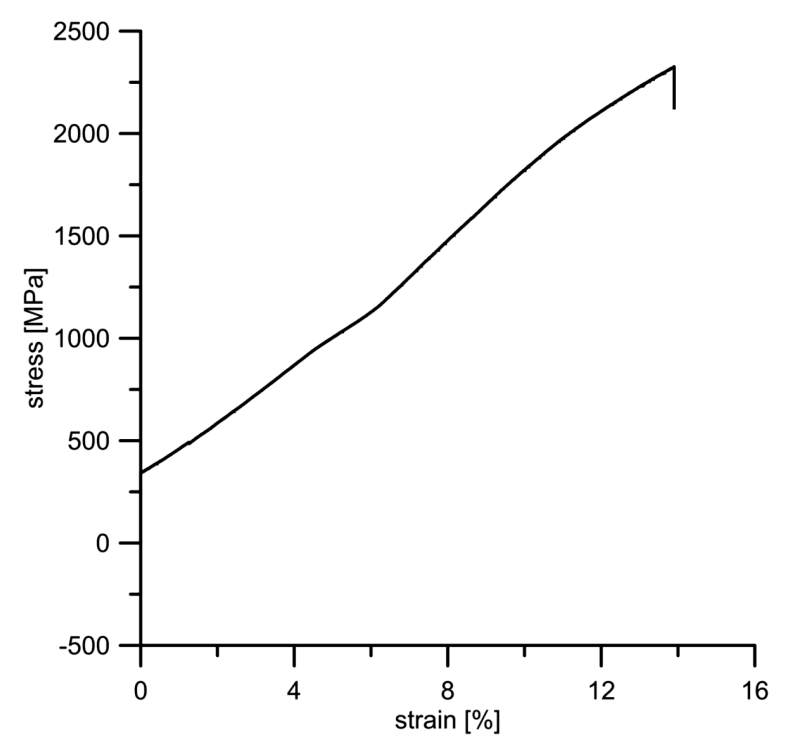

Figure 4: Stress-strain curve in compression of the NiTi alloy prepared by mechanical alloying for $120 \mathrm{~min}$ and spark-plasma sintering at $900{ }^{\circ} \mathrm{C}$ with a heating rate of $300{ }^{\circ} \mathrm{C} \mathrm{min}-1$

Slika 4: Krivulja napetost-raztezek pri tlačnem preizkusu NiTi zlitine, pripravljene $\mathrm{z}$ mehanskim legiranjem $120 \mathrm{~min}$ in sintranjem $\mathrm{z}$ iskrilno plazmo pri $900{ }^{\circ} \mathrm{C}$ in hitrostjo segrevanja $300{ }^{\circ} \mathrm{C} \mathrm{min}-1$ 


\section{MATERIALI IN TEHNOLOGIJE/MATERIALS AND TECHNOLOGY (1967-2017) - 50 LET/50 YEARS}

\section{P. NOVÁK et al.: POWDER-METALLURGY PREPARATION OF NiTi SHAPE-MEMORY ALLOY ...}

gated. In this technology, the $\mathrm{Ti}_{2} \mathrm{Ni}$ phase forms preferentially, being followed by the NiTi shape-memory phase with an austenite (B2) structure. During sparkplasma sintering of the mechanically alloyed powder, the $\mathrm{Ni}_{4} \mathrm{Ti}_{3}, \mathrm{Ni}_{3} \mathrm{Ti}$ and monoclinic NiTi develop. Due to this fact, the formation of the undesirable $\mathrm{Ti}_{2} \mathrm{Ni}$ phase cannot be avoided.

The samples achieve much higher mechanical properties than a NiTi alloy produced by conventional route, but they exhibit almost brittle behaviour. This can be caused by the change of deformation mechanism when going to nanoscale, or by trace contamination of the grain boundaries during the mechanical alloying process, lowering the cohesion of the grains.

\section{Acknowledgement}

This research was financially supported by the Czech Science Foundation, project No. 14-03044S.

\section{REFERENCES}

${ }^{1}$ M. Elahinia, M. Ahmadian, An enhanced SMA phenomenological model. Part I. The shortcomings of the existing models, Smart Materials Structures, 14 (2005), 1297-308, doi:10.1088/0964$1726 / 14 / 6 / 022$
${ }^{2}$ D. Vojtěch, M. Voděrová, J. Kubásek, P. Novák, P. Šedá, A. Michalcová, J. Fojt, J. Hanuš, O. Mestek, Effects of short-time heat treatment and subsequent chemical surface treatment on the mechanical properties, low-cycle fatigue behavior and corrosion resistance of a $\mathrm{Ni}-\mathrm{Ti}(50.9 \mathrm{at} \% \mathrm{Ni}$ ) biomedical alloy wire used for the manufacture of stents, Materials Science and Engineering A, 528 (2011), 1864-1876, doi:10.1016/j.msea.2010.10.043

${ }^{3}$ M. Elahinia, H. Ashrafiuon, Nonlinear control of a shape memory alloy actuated manipulator, Journal of Vibration and Acoustics, 124 (2002), 566-575, doi:10.1115/1.1501285

${ }^{4}$ L. Krone, E. Schüller, M. Bram, O. Hamed, H.-P. Buchkremer, D. Stöver, Mechanical behaviour of NiTi parts prepared by powder metallurgical methods, Materials Science and Engineering A, 378 (2004), 185-190, doi:10.1016/j.msea.2003.10.345

${ }^{5}$ P. Novák, A. Michalcová, J. Šerák, D. Vojtěch, T. Fabián, S. Randáková, F. Průša, V. Knotek, M. Novák, Preparation of Ti-Al-Si alloys by reactive sintering, Journal of Alloys and Compounds, 470 (2009), 123-126, doi:10.1016/j.jallcom.2008.02.046

${ }^{6}$ P. Novák, T. Kubatík, J. Vystrčil, R. Hendrych, J. Kříž, J. Mlynár, D. Vojtěch, Powder metallurgy preparation of Al-Cu-Fe quasicrystals using mechanical alloying and Spark Plasma Sintering, Intermetallics, 52 (2014), 131-137, doi:10.1016/j.intermet.2014.04.003

${ }^{7}$ T. Mousavi, F. Karimzadeh, M.H. Abbasi, Synthesis and characterization of nanocrystalline NiTi intermetallic by mechanical alloying, Materials Science and Engineering A, 487 (2008), 46-51, doi:10.1016/j.msea.2007.09.051

${ }^{8}$ T. B. Massalski, Binary Alloy Phase Diagrams, ASM, Materials Park, 1990 